\title{
Identification of adrenal genes regulated in a potassium-dependent manner
}

\author{
Alexander Dierks ${ }^{1 *}$, Urs D Lichtenauer ${ }^{1,2 *}$, Simone Sackmann ${ }^{2 *}$, \\ Ariadni Spyroglou ${ }^{1}$, Igor Shapiro ${ }^{1,2}$, Marcel Geyer ${ }^{3}$, Jenny Manonopoulou ${ }^{1}$, \\ Martin Reincke ${ }^{1}$, Constanze Hantel ${ }^{1}$ and Felix Beuschlein ${ }^{1,2}$ \\ ${ }^{1}$ Endocrine Research Unit, Medizinische Klinik-Innenstadt, Ludwig-Maximilians-University, Ziemssenstr. 1, D-80336 Munich, Germany \\ ${ }^{2}$ Institute of Molecular Medicine and Cell Research, Albert-Ludwigs-University Freiburg, D-79085 Freiburg, Germany \\ ${ }^{3}$ Department of Internal Medicine IV, Albert-Ludwigs-University Freiburg, D-79104 Freiburg, Germany \\ (Correspondence should be addressed to F Beuschlein who is now at Department of Medicine, Endocrine Research, University Hospital Innenstadt, \\ Medizinische Klinik-Innenstadt, Ziemssenstr. 1, D-80336 Munich, Germany; Email: felix.beuschlein @ med.uni-muenchen.de) \\ *(A Dierks, U D Lichtenauer and S Sackmann contributed equally to this work)
}

\begin{abstract}
Potassium and angiotensin II are the main stimulators of aldosterone secretion from the adrenal cortex. As potassiuminduced in vivo gene regulation in the adrenal cortex has not been studied in detail, we applied a stepwise screening approach: first, we investigated the effects of chronic potassium substitution in mice. Microarray analysis of adrenal glands revealed a set of genes (set A) that were counter-regulated in a high potassium (HP) and low potassium substitution group, while others (set B) were highly upregulated in the HP intake group. In a second step, time dependency of expression changes of these pre-defined genes was studied following short-term potassium stimulation experiments in vivo. Thirdly, dose dependency of potassium-induced gene regulation was investigated in vitro. Finally, to provide indirect evidence for the potential relevance of the detected changes for autonomous aldosterone secretion, expression analysis of aldosterone-producing adenomas was compared with normal adrenal glands. While most investigated genes were similarly regulated following long- and short-term potassium stimulation in vivo, observed changes were reproducible in $\mathrm{NCl}$ h295R adrenocortical cells mostly for the set of genes identified in the HP group (set B) . Similarly, in Conn's adenomas, mostly genes from set B displayed changes in expression pattern in comparison to normal adrenal glands, while genes from set A were mostly unchanged. Thus, while in vivo models can help in identifying genes potentially involved in potassium-dependent aldosterone secretion, these findings also underline the necessity to interpret potassium-induced gene regulation on the basis of the experimental setting.
\end{abstract}

Journal of Molecular Endocrinology (2010) 45, 193-206

\section{Introduction}

Aldosterone through induction of sodium reabsorption and potassium secretion in the renal distal tubulus is a major regulator of electrolyte balance, intravascular volume, and blood pressure (Williams \& Williams 2003). As evident in the context of primary aldosteronism, dysregulation of aldosterone secretion has deleterious effects with high incidence of cardiovascular events (Vasan et al. 2004, Milliez et al. 2005, Stowasser et al. 2005), metabolic alterations (Sindelka et al. 2000, Widimsky et al. 2000, Fallo et al. 2006), and renal damages (Rossi et al. 2006), which exceed those observed in patients with essential hypertension. Despite the high incidence of primary aldosteronism (Mulatero et al. 2004), the molecular mechanisms that contribute to autonomous aldosterone secretion only begin to emerge.
Aldosterone is released by the cells of the adrenal zona glomerulosa, but stored only in minimal quantities. Thus, ad hoc biosynthesis of aldosterone needs to be tightly regulated to maintain fluid and electrolyte homeostasis (Bassett et al. 2004b). Transcriptional activation and post-transcriptional modification of steroidogenic enzymes are the major regulatory mechanisms for acute and chronic modulation of adrenocortical steroid production and release (Christenson \& Strauss 2001). There are two main rate-limiting steps for aldosterone synthesis: transport of cholesterol to the inner mitochondrial membrane is mediated by the steroidogenic acute regulatory protein (Lin et al. 1995, Cherradi et al. 1998) and the conversion of 11-deoxycorticosterone to aldosterone, a process which is catalyzed by aldosterone synthase (Curnow et al. 1991). Expression of aldosterone synthase, which is encoded by $C Y P 11 B 2$, is primarily

DOI: 10.1677/JME-09-0171 Online version via http://www.endocrinology-journals.org 
stimulated by extracellular potassium concentration and by angiotensin II. This transcriptional regulation had initially been described in the context of chronic (hours to days) in vitro stimulation experiments (Denner et al. 1996, Clyne et al. 1997). However, in vivo, adrenal CYP11B2 levels increase even within minutes upon specific stimulation experiments (Spyroglou et al. 2009). Both potassium and angiotensin II can act independently and have equivalent effects on transcriptional regulation of CYP11B2. Glomerulosa cells are very sensitive to changes in extracellular potassium concentrations with aldosterone secretion in vivo (Boyd et al. 1971) and production in vitro (Boyd \& Mulrow 1972, Varnai et al. 1998) stimulated by changes of potassium levels as low as $0.1 \mathrm{mM}$. An important mediator of potassium- and angiotensin II-induced aldosterone secretion is intracellular calcium content (Yagci \& Muller 1996, Pezzi et al. 1997). Whereas elevation of extracellular potassium concentrations results in calcium influx through T-and L-type channels, angiotensin II also leads to calcium release from intracellular stores (Lotshaw 2001, Akizuki et al. 2008). The increase in intracellular calcium acts through the calcium-binding protein calmodulin, which activates calcium/calmodulin-dependent protein kinase I and IV (CaMK I/IV; Condon et al. 2002) which, in turn, activates various transcription factors including NURR1, NGFIB, ATF-1, and CREB (Bassett et al. 2004a,b). These transcription factors interact with defined sites in the $5^{\prime}$-flanking region of $C Y P 11 B 2$ and enhance the transcription of aldosterone synthase (Clyne et al. 1997, Bassett et al. 2004b).

While these molecular mechanisms have been characterized in quite some detail over the last years, it is evident that potassium can induce a multitude of molecular changes that could also be involved in the regulation of aldosterone secretion. In an attempt to define novel pathways in the adrenal gland which are modulated in a potassium-dependent manner, we applied microarray techniques on adrenals from mice after specific stimulation paradigms. Upon long-term potassium substitution experiments, we identified a set of genes that were regulated in a potassium-dependent manner. These genes were further investigated in independent in vivo and in vitro experiments and finally explored for their potential involvement in autonomous aldosterone secretion.

\section{Materials and methods}

\section{Animal experiments}

All experiments were carried out following protocols examined and approved by the Regierung von Oberbayern and in accordance with the German guidelines for animal studies. Animals were maintained under standard conditions of temperature $\left(22^{\circ} \mathrm{C}\right)$ with $12 \mathrm{~h}$ light: $12 \mathrm{~h}$ darkness cycles and food and water ad libitum.

\section{Long-term stimulation experiments}

To explore long-term effects of potassium stimulation on aldosterone secretion and concurrent transcriptional regulation, 8-week-old male CD-1 mice (Charles River Laboratories, Sulzfeld, Germany) were separated in three groups of 30 animals each and maintained under different diets for 28 days. While the low potassium (LP) group received chow with $7171 \mathrm{mg} / \mathrm{kg}$ potassium and distilled water, the high potassium (HP) group was fed with chow containing $11380 \mathrm{mg} / \mathrm{kg}$ potassium and drinking water that was substituted with $2 \% \mathrm{KCl}$. Control (Co) animals were kept with regular chow containing $9100 \mathrm{mg} / \mathrm{kg}$ potassium and distilled drinking water.

On day 28, mice were euthanized, and trunk blood was collected for hormonal measurements within $1 \mathrm{~min}$ after initial handling. All adrenals were immediately cleaned from adjacent tissue using a stereomicroscope, snap frozen in liquid nitrogen, and stored at $-80^{\circ} \mathrm{C}$ until further processing. From each animal, one adrenal was used for RNA extraction, while the other was utilized for morphological examination.

\section{Short-term potassium stimulation}

For short-term potassium stimulation, 12-week-old female C3H mice (Jackson Laboratories, Bar Harbor, ME, USA) received drinking water ad libitum that was supplemented with $2 \% \mathrm{KCl}$. After 1, 4, and 7 days respectively, five mice per time point were euthanized for collection of trunk blood and adrenal samples. For baseline controls, another group of mice was euthanized without specific prior treatment. Blood and tissue sampling was performed as described above.

\section{Surgical tissue samples}

Diagnosis of aldosterone-producing adenomas was made according to established criteria including documentation of primary aldosteronism, aldosterone production by the tumor, histological diagnosis, and relief of symptoms upon surgical intervention. Adenoma samples were collected during the German and Austrian Adrenal Network Multicenter Trial (Saeger et al. 2003), whereas normal adrenal glands were obtained from patients undergoing nephrectomy and adrenalectomy because of kidney cancer. After removing adjacent fat tissue, the adrenal samples were snap frozen in liquid nitrogen and immediately stored at $-80^{\circ} \mathrm{C}$ until analyzed. The study protocol was approved by the local ethics committees of the 
Universities of Würzburg and Freiburg. A total of 12 patients with aldosterone-producing adenomas and 6 normal adrenal samples were included in the expression studies.

\section{Morphological examinations}

For morphological evaluation of murine adrenal glands, tissue samples were fixed in paraformaldehyde, embedded in paraffin, sectioned, and azan stained following standard procedures. Stained sections were examined with a standard light microscope using $50 \times$ magnification, and areas representing the zona glomerulosa were quantified as square pixels using the SPOT software (Version 3.5.5; Diagnostic Instruments, Inc., Sterling Heights, MI, USA).

\section{Aldosterone measurement}

Aldosterone was determined with an in-house timeresolved fluorescence immunoassay as recently described in detail (Manolopoulou et al. 2008). Analytical sensitivity of the assay was $8 \mathrm{pg} / \mathrm{ml}$; intra-assay coefficients of variation at concentrations of 18,34 , and $139 \mathrm{pg} / \mathrm{ml}$ were $7 \cdot 3,6 \cdot 3$, and $4 \cdot 4 \%$ respectively. Interassay coefficients were $15 \cdot 2,15 \cdot 1$, and $8 \cdot 0 \%$ respectively.

\section{Microarray analysis}

Twenty-two thousand murine cDNA microarrays were produced and processed essentially according to the Stanford protocol described by Eisen \& Brown (1999). The library of 22000 murine cDNAs was obtained as bacterial stocks from the National Institute of Aging (http://lgsun.grc.nia.nih.gov/cDNA/15k.html, http://lgsun.grc.nia.nih.gov/cDNA/NIA_7_4k.html), kindly distributed by the MRC, Cambridge, UK (Tanaka et al. 2000, VanBuren et al. 2002). Plasmids were purified using the Qiagen 96-well Turbo Kit (Qiagen). Inserts were purified by PCR using vector primers flanking the individual inserts (5'-CTG CAA GGC GAT TAA GTT GGG TAA C-3' ${ }^{\prime}$ and $5^{\prime}$-GTG AGC GGA TAA CAA TTT CAC ACA GGA AAC AGC-3'). The PCR products were purified by ethanol precipitation, and resuspended in $\mathrm{H}_{2} \mathrm{O}$. The aliquots were dried and resuspended in $3 \times$ SSC to a final concentration of $\sim 40 \mathrm{ng} / \mu \mathrm{l}$ for printing. Microarray printing was performed on aminosilane-coated slides (CMT-GAP II Slides; Corning Inc., Wiesbaden, Germany), using an arrayer that was assembled according to specifications by the Stanford group. The arrayer was operated using software kindly provided by Joe de Risi (http://cmgm.stanford.edu/pbrown).

Twenty-four micrograms of either tissue or reference RNA were transcribed into cDNA in the presence of Cy3- or Cy5-labeled dUTP, using Superscript-II reverse transcriptase (Invitrogen). Hybridizations were performed in the presence of an equal amount of reference RNA (Stratagene, La Jolla, CA, USA) as described by Boldrick et al. (2002). All other steps, including hybridization, were performed according to the protocol provided by Brown et al. (http://cmgm. stanford.edu/pbrown).

Spot signal intensities were measured with an Axon 4000A scanner using commercially available software (GenePix 4.1, Axon Instruments, Union City, CA, USA). Printing artifacts were screened for and excluded manually if not detected by the software. Image and data files, array layout, and all relevant information requested by the minimum information about a microarray experiment (MIAME) guidelines (Brazma et al. 2001) were transferred to the GeneTrafficDuo database (Iobion Informatics, La Jolla, CA, USA). In order to exclude artifacts near background range, all cDNA spots were eliminated when sample intensity or reference intensity was $<50$ or less than the local background. Local background was subtracted from spot intensities. A locally weighted scatter plot smoother subgrid normalization method was used for normalization. Following an approach proposed by Dudoit $e t a l$. (2002), the computed expression ratios depend on the intensity of the spots. Thus, a smooth nonlinear leastsquares fit was computed to correct for an intensitydependent bias. Initially, the log ratio of measured Cy3 and $\mathrm{Cy} 5$ values obtained from the image analysis software was computed. The complete set of expression data has been made available at http:/ / www.endocrine-research. mki.klinikum.uni-muenchen.de/en/download/.

\section{In vitro experiments}

The NCI h295R tumor cell line obtained from the ATCC collection (ATCC-LGC, Wesel, Germany) was cultured as described earlier (Betz et al. 2005) in RPMI 1640 medium supplemented with $10 \%$ fetal bovine serum, $1 \%$ insulintransferrin-selenium supplement, $1 \%$ penicillin/ streptomycin, and $1 \times 10^{-8} \mathrm{M}$ hydrocortisone. For stimulation experiments, cells were split onto 6-well culture dishes in a density of 850000 cells/well and allowed to grow for $48 \mathrm{~h}$. Cells were then treated with 0,5 , or $20 \mathrm{mM}$ potassium chloride added to the culture medium for a period of $48 \mathrm{~h}$. From each individual well, supernatant was collected for aldosterone measurement, and cells were harvested for RNA extraction respectively.

\section{Luciferase experiments}

NCI h295R cells were split onto 96-well culture dishes in a density of 20000 cells/well and allowed to grow for $48 \mathrm{~h}$. Cells were co-transfected with the phRL-CMV plasmid and the pGL4.10[luc2]-hCYP11B2 plasmid 
(kind gift from Dr C Gomez-Sanchez, University of Mississippi) using TransFast Transfection Reagent (Promega). Cells were then treated with 0 to $20 \mathrm{mM}$ potassium chloride added to the cell culture medium for a period of $48 \mathrm{~h}$. Supernatant from each individual well was collected for aldosterone measurement. Luciferase activity was determined with a luminometer (Mithras Reader, Berthold Technologies, Bad Wildbach, Germany) using the Dual-Luciferase Reporter Assay System (Promega) in accordance with the manufacturer's protocol. Firefly luciferase activity from pGL4.10[luc2]-hyCYP11B2 plasmid was normalized to the renilla luciferase activity from phRL-CMV plasmid. Results were expressed in percentage in comparison to the untreated control.

\section{Real-time PCR}

RNA from murine adrenals, surgical samples, and in vitro experiments was extracted using the SV Total RNA Extraction system (Promega) followed by reverse transcription (RevertAid H Minus First Strand cDNA Synthesis Kit, Fermentas, St Leon-Rot, Germany) in accordance with the manufacturer's protocol. For realtime PCR analyses, the FastStart DNA MasterPLUS SYBR Green I reaction mix was utilized in the LightCycler 1.5 (Roche). The cycling program for real-time PCR started with a pre-incubation step at $95{ }^{\circ} \mathrm{C}$ for $10 \mathrm{~min}$, followed by an amplification step that consisted of 40 cycles at $95{ }^{\circ} \mathrm{C}$ for $15 \mathrm{~s}$, annealing for $30 \mathrm{~s}$ (annealing temperature primer specific mentioned below), and an extension step at $72{ }^{\circ} \mathrm{C}$ for which the time depending on product length in bps divided by 25 (Roche). Primer sequences as well as product length and annealing temperatures are summarized in Table 1.

The melting curve analysis was performed between 65 and $95^{\circ} \mathrm{C}\left(0 \cdot 1{ }^{\circ} \mathrm{C} / \mathrm{s}\right)$ to determine the melting temperature of the amplified product and to exclude undesired primer dimers. Furthermore, the products were run on a $1 \%$ agarose gel to verify the amplified product. Quantification was adjusted using the housekeeping gene $\beta$-actin for murine samples and HPRT for human samples. To facilitate overall comparison of individual real-time PCR experiments, expression levels of the particular genes were set as $100 \%$ for the control. For each time point, expression levels were expressed as percentage increase or decrease from baseline levels respectively.

\section{Statistical analysis}

All results are expressed as mean \pm s.e.m. Statistical significance was determined by an unpaired $t$-test using Prism 5 (GraphPad Software Inc., La Jolla, CA, USA). Statistical significance was defined as $P<0.05$ and is denoted by asterisks $(* P<0 \cdot 05 ; * * P<0 \cdot 01 ; * * * P<0 \cdot 001)$ in the figures if not stated otherwise.

For statistical analysis of differentially expressed genes from the microarray experiments, a two-sample $t$-test was used. The computed $P$ values were adjusted using a false discovery rate-controlling algorithm (Benjamini \& Hochberg 1995). Genes with an adjusted $P$ value of $<0.05$ were selected, and agglomerative hierarchical clustering as introduced by Kaufman \& Rousseeuw (1990) was performed using the R statistical software package (www.r-project.org).

\section{Results}

\section{Global analysis of potassium-induced gene regulation}

In the first instance, we investigated long-term effects of potassium supplementation on murine adrenal morphology and transcriptional regulation of aldosterone synthase in vivo. Despite the fact that no significant differences in serum potassium levels were observable in the applied in vivo models, upon chronic potassium substitution over 4 weeks, treated animals displayed a $3 \cdot 5$-fold increase in plasma aldosterone ( $1151 \pm 98$ vs $315 \pm 46 \mathrm{pg} / \mathrm{ml} ; P<0 \cdot 001$, Fig. 1A) and a $12 \cdot 5$-fold increase in adrenal Cyp11b2 expression $(1279 \cdot 2 \pm 102 \cdot 3$ vs $100 \pm 5.4 \%$; $P=0.0003$, Fig. $1 \mathrm{~B})$ compared to mice under regular diet. On a morphological scale, only minor changes were evident with a slight increase of zona glomerulosa thickness in HP-treated mice in comparison to the control group $(122 \cdot 2 \pm 9 \cdot 5$ vs $100 \pm 3 \cdot 8 \% ; P=0 \cdot 04$, Fig. 1C). In contrast to animals from the HP group, no significant changes in these endpoints were detectable between animals kept under LP diet and Co (plasma aldosterone, 266 \pm 47 vs $315 \pm 46 \mathrm{pg} / \mathrm{ml} ; \quad P=\mathrm{NS} ; \quad C y p 11 b 2$ expression, $186.5 \pm 16 \cdot 4$ vs $100 \pm 5 \cdot 4 \% ; P=\mathrm{NS}$; area of zona glomerulosa, $117 \cdot 4 \pm 5 \cdot 9$ vs $100 \pm 3 \cdot 8 \% ; P=\mathrm{NS}$ ).

Using this in vivo model, we applied microarray expression analysis to identify genes in the adrenal gland that were differently regulated under chronic potassium supplementation. In accordance with the initial phenotypic characterization, differences in gene regulation were much more prominent in the HP group (set B, 2189 genes regulated $>1 \cdot 5$-fold over Co group with $P<0 \cdot 05$; Table 2$)$ than in animals following LP treatment (72 regulated genes). For further realtime PCR analysis, we choose those genes (set A) that displayed opposite regulation in the HP and LP groups in comparison to the Co animals (Fig. 2A). Based on these experiments, expression of Mtus 1 (HP, $354 \cdot 5 \pm 41 \cdot 3$ versus Co, $100 \pm 7 \cdot 3 \%$, LP, $85 \cdot 3 \pm 16 \cdot 7 \%$; $P<0.01)$, Smoc1 (HP, $531.9 \pm 25.9 \%$ versus Co, $100 \pm 15 \cdot 4 \%$, LP, $44 \cdot 9 \pm 6 \cdot 1 \% ; P<0 \cdot 001)$, and $G p r 48$ 
Table 1 Primer sequences used for quantitative PCR analysis

\begin{tabular}{|c|c|c|c|c|}
\hline & Species & Primer sequence & $\begin{array}{l}\text { Annealing } \\
\text { temperature }\left({ }^{\circ} \mathrm{C}\right)\end{array}$ & $\begin{array}{l}\text { Amplification } \\
\text { product (bp) }\end{array}$ \\
\hline \multicolumn{5}{|l|}{ Gene (accession number) } \\
\hline Cyp11b2 (NM_009991.2) & Mouse & $\begin{array}{l}\text { 5'-CAGGGCCAAGAAAACCTACA-3' } \\
5^{\prime} \text {-ACGAGCATTTTGAAGCACCT-3' }\end{array}$ & 63 & 368 \\
\hline Mtus1 (NM_001005863) & Mouse & 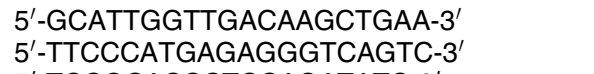 & 55 & 193 \\
\hline Tcf4 (NM_009333.2) & Mouse & $\begin{array}{l}\text { 5'-TCCGCACCCTCCAGATATC-3' } \\
\text { 5'-GAGTGAGCCGACGTCACTC-3' }\end{array}$ & 55 & 295 \\
\hline Gpr48 (NM_172671.2) & Mouse & $\begin{array}{l}\text { 5'-GACTTCGCATTCACCAACCT-3' } \\
5^{\prime} \text {-GCCTGAGGAAATTCATCCAA-3' }\end{array}$ & 54 & 148 \\
\hline Wwox (NM_019573.2) & Mouse & $\begin{array}{l}\text { 5'-CGAGTCCCACAGATTTACAG-3' } \\
\text { 5'-GCAGTTCATTGGAGAAGAGG-3' }^{\prime}\end{array}$ & 142 & 62 \\
\hline Smoc1 (NM_022316.1) & Mouse & $\begin{array}{l}\text { 5'-CACCACAGACATGGTTCAGG-3' } \\
\text { 5'-TGTTCAGGTCGCAGTAGTCG-3' }\end{array}$ & 55 & 241 \\
\hline Sos1 (NM_009231.2) & Mouse & $\begin{array}{l}\text { 5'-GGAACAGTAAGAGGTAAAGCA-3' } \\
5^{\prime} \text {-TTCTATTGGGTGTAAGGTGAG-3' }\end{array}$ & 62 & 194 \\
\hline$\beta$-actin (NM_007393) & Mouse & $\begin{array}{l}\text { 5'-TCATGAAGTGTACGTGGACATCC-3' } \\
\text { 5'-CCTAGAAGCATTTGCGGTGGACGATG-3' }^{\prime}\end{array}$ & 56 & 282 \\
\hline MTUS1 (NM_001001925.2) & Human & $\begin{array}{l}\text { 5'-GGACAACAACACAGCATTGG-3' } \\
5^{\prime} \text {-TCCACAGAAGCTCCTCGTTT-3 }{ }^{\prime}\end{array}$ & 54 & 193 \\
\hline TCF4 (NM_030756.3) & Human & $\begin{array}{l}\text { 5'-GGAAAGTTTGGAAGAAGCGG-3' } \\
\text { 5'-ATTTCATCTGGAGATAGGTTCGG-3' }^{\prime}\end{array}$ & 60 & 157 \\
\hline GPR48 (NM_018490.2) & Human & $\begin{array}{l}\text { 5'-GCCTGAATGGGCTAAATCAA-3' } \\
\text { 5'-TGGTCCTGGAGGCTGTTATC-3 }^{\prime}\end{array}$ & 55 & 180 \\
\hline WWOX (NM_016373.1) & Human & $\begin{array}{l}\text { 5'-TGGAGCTAATTCAGGAATAGGG-3' } \\
\text { 5'-ATGAAGAGGCACATTCTTGG-3 }^{\prime}\end{array}$ & 60 & 225 \\
\hline SOS1 (NM_005633.3) & Human & $\begin{array}{l}\text { 5'-AAACGAAGACTGAGTGAATCTG-3' } \\
\text { 5'-CTCCCAACCATCAATATTCTTCTG-3' }\end{array}$ & 61 & 110 \\
\hline HPRT (NM_000194.2) & Human & $\begin{array}{l}\text { 5'-TGCTGACCTGCTGGATTACA-3' } \\
\text { 5'-CCTGACCAAGGAAAGCAAAG-3' }^{\prime}\end{array}$ & 57 & 229 \\
\hline NKTR (NM_00385) & Human & $\begin{array}{l}\text { 5'-CAGTTCAGAAGAGCCAAGGA-3' } \\
5^{\prime} \text {-CAGGAATCTTCGGTTCAGGT-3' }\end{array}$ & 62 & 211 \\
\hline LPHN3 (NM_015236.4) & Human & $\begin{array}{l}5^{\prime} \text {-AAACATATCAAGCAGTCAGAGG-3' } \\
5^{\prime} \text {-CAAATCAGGAGACAAACAAGG-3 }\end{array}$ & 60 & 271 \\
\hline SPP1 (NM_001040058.1) & Human & $\begin{array}{l}\text { 5'-GTGCCATACCAGTTAAACAG-3' } \\
\text { 5'-TCATCTACATCATCAGAGTCGT-3 }^{\prime}\end{array}$ & 60 & 294 \\
\hline MAGI1 (NM_004742.2) & Human & $\begin{array}{l}\text { 5'-AATACCACCAAACCAAAGCAG-3' } \\
\text { 5'-CATCACCAATCCTCATCTTTCC-3' }\end{array}$ & 60 & 213 \\
\hline HMOX2 (NM_001127204.1) & Human & $\begin{array}{l}\text { 5'-AACCAAATGAGAATGGCTGAC-3' } \\
\text { 5'-GGCTGAGTATGTGAAGTAAAGTG-3' }^{\prime}\end{array}$ & 60 & 164 \\
\hline RNF144B (NM_182757) & Human & $\begin{array}{l}\text { 5'-TGAAAGAGAAGTTCATCTGGAC-3' } \\
\text { 5'-TCATTGCGTTCGATATAAACCC-3 }^{\prime}\end{array}$ & 59 & 287 \\
\hline
\end{tabular}

(HP, $297 \pm 31 \cdot 9 \%$ versus Co, $100 \pm 6 \%$, LP, $87 \cdot 9$ $\pm 14 \cdot 4 \% ; P<0 \cdot 01)$ was significantly upregulated in HP-treated mice compared with controls and mice after LP treatment. Furthermore, we detected a significant increase in expression levels for Tcf4 (LP, $143 \pm 4 \cdot 8 \%$ versus Co, $100 \pm 9 \% ; P=0 \cdot 006)$, Sos 1 (LP, $148 \cdot 1 \pm 8 \cdot 5 \%$ versus Co, $100 \pm 6 \cdot 9 \% ; P=0 \cdot 005$ ), and Wwox (LP, 202.8 $\pm 13 \cdot 3 \%$ versus Co, $100 \pm 4 \cdot 9 \%$; $P=0 \cdot 0003)$ in the LP group in comparison to the Co group. For Tcf4 (LP, $143 \pm 4.8 \%$ versus HP, $84 \pm 8 \%$; $P=0 \cdot 0007)$ and Sos 1 (LP, $148 \cdot 1 \pm 8 \cdot 5 \%$ versus HP, $90 \cdot 5 \pm 7 \cdot 1 \% ; P=0 \cdot 002)$, a significant increase in gene expression was also detectable after LP treatment in comparison to the HP stimulation.

\section{Regulation of candidate genes following short-term potassium stimulation in vivo}

To further explore the observed transcriptional changes in a time-dependent manner in an independent experiment, groups of animals of different gender and genetic background were kept under HP supplementation between 1 and 7 days followed by measurement of plasma aldosterone and Cyp11b2 expression levels in the adrenals. As expected, potassium treatment significantly increased plasma aldosterone levels in comparison to baseline values over the observation period with a peak after 1 day (day $1,298 \pm 59 \mathrm{pg} / \mathrm{ml}$, $P<0 \cdot 01$; day $4,226 \pm 11 \mathrm{pg} / \mathrm{ml}, P<0.001$; day 7 , 

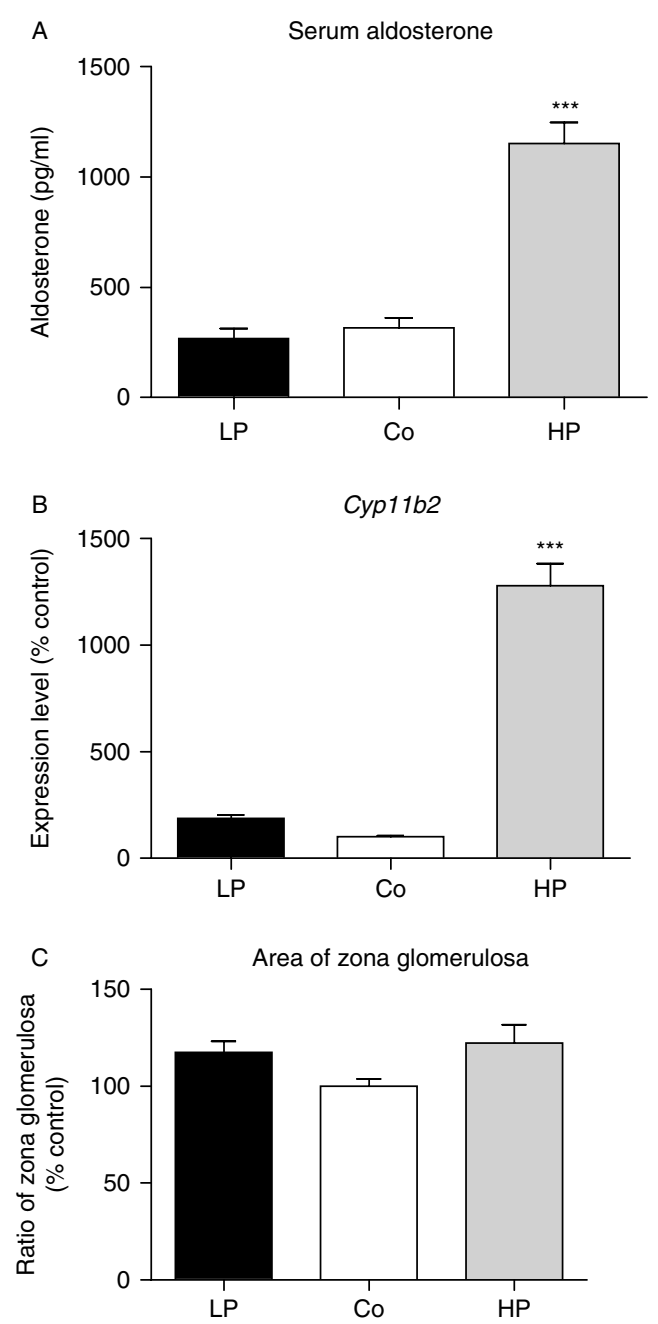

Figure 1 Serum aldosterone concentrations (A), aldosterone synthase (Cyp11b2) expression level (B), and ratio of zona glomerulosa area (C) in murine adrenal glands after different potassium substitution (LP, low potassium; Co, control; HP, high potassium). Asterisks denote significant differences in comparison to untreated controls.

$170 \pm 24 \mathrm{pg} / \mathrm{ml}, P<0 \cdot 05$ versus baseline, $88 \pm 11 \mathrm{pg} / \mathrm{ml}$; Fig. 3A). Similarly, for adrenal Cyp11b2 expression levels, a twofold elevation over baseline was detectable upon potassium substitution in comparison to untreated controls (day $1,191 \cdot 2 \pm 26 \cdot 7 \%, P<0 \cdot 03$; day $4,192 \cdot 6 \pm 59 \cdot 9 \%, P=\mathrm{NS}$; day $7,215 \pm 48 \cdot 4 \%$, $P=$ NS versus baseline, $100 \pm 20 \%$; Fig. 3B).

In a second step, we analyzed the expression levels of those candidate genes that we had identified to be differently regulated under long-term potassium stimulation (set A). A significant increase in expression over baseline values was detectable after 1,4 , and 7 days of potassium substitution for Mtus1 (day 1, 153 $\pm 20.4 \%$, $P=0.041 ;$ day $4,162 \pm 28.4 \%, P=0.036$; day 7 , $156 \cdot 7 \pm 30 \%, P=$ NS versus baseline, $100 \pm 12 \cdot 2 \%$;
Fig. 3C) and also for Smoc1 (day 1, 106.9 $\pm 18 \%$, $P=\mathrm{NS}$; day $4,149 \cdot 5 \pm 25 \cdot 3 \%, P=\mathrm{NS}$; day $7,192 \cdot 9$ $\pm 17 \cdot 4 \%, \quad P=0 \cdot 02$ versus baseline, $100 \pm 25 \cdot 3 \%$; Fig. 3G). Conversely, a significant decrease in expression over baseline was detectable for $G p r 48$ (day $1,49 \cdot 7 \pm 5 \cdot 5 \%, P=0 \cdot 03$; day $4,37 \cdot 8 \pm 7 \cdot 3 \%, P=0 \cdot 013$; day $7,30 \cdot 4 \pm 4 \cdot 4 \%, P=0 \cdot 006$ versus baseline, $100 \pm 17 \cdot 3 \%$; Fig. 3E), Tcf4 (day 1, 42士4.5\%, $P=0.0097$; day 4, $35 \pm 4 \cdot 2 \%, P=0 \cdot 0052$; day $7,45 \cdot 2 \pm 9 \cdot 1 \%, P=0 \cdot 02$ versus baseline, $100 \pm 15 \cdot 6 \%$; Fig. 3D), Sos1 (day 1, $51 \cdot 3 \pm 7.5 \%, P=0.0045$; day $4,30 \cdot 8 \pm 7 \cdot 5 \%, P=0.0005$; day $7,24 \pm 5.9 \%, P=0.0002$ versus baseline, $100 \pm 10 \%$; Fig. $3 \mathrm{H}$ ), and $W w o x($ day $1,72 \cdot 4 \pm 20 \cdot 2 \%, P=\mathrm{NS}$; day 4 , $41 \cdot 1 \pm 11 \cdot 8 \%, \quad P=0.0022 ; \quad$ day $7, \quad 50 \cdot 9 \pm 11 \cdot 4 \%$, $P=0.0058$ versus baseline, $100 \pm 8 \cdot 2 \%$; Fig. $3 \mathrm{~F}$ ). Thus, with the exception of $G p r 48$, the investigated candidate genes displayed comparable changes in expression levels upon chronic and short-term potassium supplementation even as for those experiments (long versus short supplementation), animals of different age, gender, and genetic background had been chosen.

\section{Effects of in vitro potassium stimulation on the expression levels of candidate genes}

To further substantiate our results in a well-defined in vitro system, the human adrenocortical tumor cell line NCI h295R was incubated with various amounts of potassium chloride (ranging from $5 \cdot 8$ to $25 \cdot 8 \mathrm{mM}$ final concentration) added to the medium. After incubation for $48 \mathrm{~h}$, aldosterone synthase promoter activity and aldosterone secretion were measured. As expected and in accordance with the literature (Clyne et al. 1997), potassium supplementation resulted in a dosedependent upregulation of CYP11B2 promoter activity and aldosterone production in the cell culture supernatant (Fig. 4A and B). Accordingly, potassiumdependent induction of endogenous CYP11B2 expression could be demonstrated in a dose-dependent manner $\left(5.8 \mathrm{mM} \mathrm{K}^{+}, 100 \pm 10.8 \% ; 10.8 \mathrm{mM} \mathrm{K}^{+}\right.$, $367 \cdot 0 \pm 85 \cdot 3 \%, P=0 \cdot 036 ; 25 \cdot 8 \mathrm{mM} \mathrm{K}^{+}, 1985 \pm 212 \cdot 3 \%$, $P=0 \cdot 0009$; Fig. 4C). Despite these expected and clear responses in well-defined experimental endpoints, changes in expression levels in the pre-defined candidate genes from set A (Fig. 4D) were either not significantly different from baseline levels (for TCF4, GPR48, and SOS1, Fig. 4E, F, and H) or displayed differences that were even opposed to those observed in the in vivo experiments (WWOX: $10 \cdot 8 \mathrm{mM} \mathrm{K} \mathrm{K}^{+}$, $149 \pm 15 \cdot 3 \% ; P=0 \cdot 0102 ; 25 \cdot 8 \mathrm{mM} \mathrm{K}{ }^{+}, 262 \pm 21.5 \%$; $P<0 \cdot 0001$ vs $\left.5 \cdot 8 \mathrm{mM} \mathrm{K}^{+}, 100 \pm 2 \%\right)$. Only MTUS was upregulated by potassium similar to what had been detected in long-and short-term potassium stimulation in vivo $\left(10.8 \mathrm{mM} \mathrm{K}^{+}, 105 \pm 7.5 \% ; P=\mathrm{NS} ; 25.8 \mathrm{mM} \mathrm{K}^{+}\right.$, $130 \pm 9 \% ; P<0 \cdot 05$ vs $\left.5 \cdot 8 \mathrm{mM} \mathrm{K}^{+}, 100 \pm 6 \cdot 8 \%\right)$. 
Table 2 Genes upregulated in adrenals from mice under chronic high potassium supplementation in comparison to control animals (set B)

Gene name

Gene ID
BG068446
BQ553208
BG063118
BG064470
BG070062
BQ551455
AA408927
BG075413
BG081591
BG069986
BQ555253
BG077012
BQ561647
BG075763
BG064926
BG062945
BG076175
AA408929
BG075611
BG071965
BG065028
BQ560671
BQ552612
BG063496
BQ562474
BQ555316
BG063063
BG076012
BG068695
AW538243

Latrophilin 3

Cyclin A2

F11 receptor

Cyclin B1

Integrin $\alpha 1$
RIKEN cDNA A830008007 gene

IBR domain containing 2

Inner centromere protein

Membrane-associated guanylate kinase,

WW and PDZ domain containing 1

Secreted phosphoprotein 1

Natural killer tumor recognition sequence

RIKEN cDNA C230081A13 gene

Heme oxygenase (decycling) 2

Chromogranin B

Cell division cycle 6 homolog (S. cerevisiae)

DNA segment, Chr 12, ERATO Doi 551, expressed

Antigen identified by monoclonal antibody Ki- 67

Synaptojanin 2 binding protein

DNA segment, Chr 18, ERATO Doi 653, expressed

Zinc finger $\mathrm{CCCH}$ type containing 5

Leukocyte immunoglobulin-like receptor, subfamily B (with TM and ITIM domains), member 3

Ubiquitin-like, containing PHD and RING finger domains, 1

Cysteine-rich protein 61

Chromodomain helicase DNA binding protein 6

Centrosomal protein 55

CD44 antigen

Chromogranin A

UDP- $N$-acetyl- $\alpha$-D-galactosamine: polypeptide

$\mathrm{N}$-acetylgalactosaminyltransferase 7

ATPase type 13A3

Transcribed locus

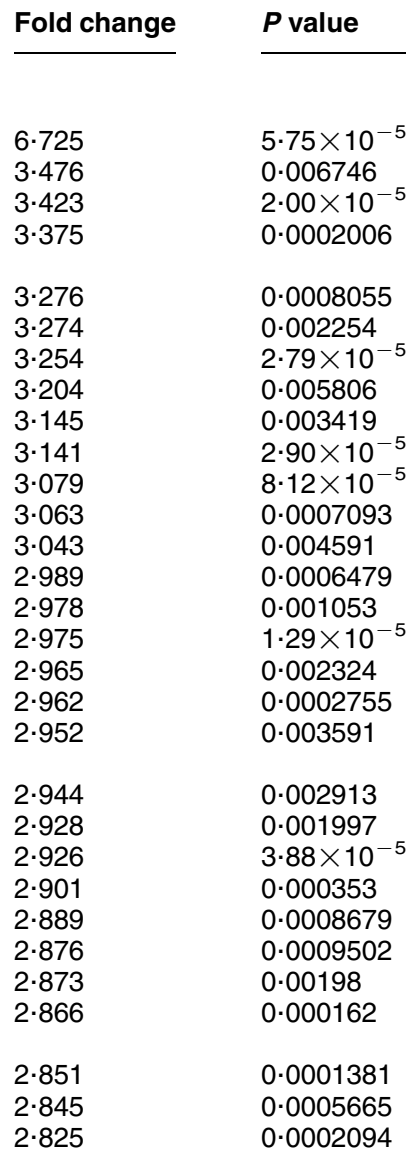

In contrast, genes from set $\mathrm{B}$ displayed more consistent transcriptional changes in accordance with the long-term in vivo substitution experiment: from the investigated genes, only NKTR showed potassium-induced downregulation $\left(10.8 \mathrm{mM} \mathrm{K} \mathrm{K}^{+}\right.$, $111.7 \pm 13.5 \%, P=\mathrm{NS} ; 25.8 \mathrm{mM} \mathrm{K}{ }^{+}, 57 \cdot 6 \pm 8 \cdot 0 \%$; $P<0.05$ vs $5.8 \mathrm{mM} \mathrm{K}^{+}, 100 \pm 11.7 \%$ ), while $L P H N 3$ $\left(10.8 \mathrm{mM} \mathrm{K} \mathrm{K}^{+}, \quad 126.5 \pm 25.9 \%, \quad P=\mathrm{NS} ; \quad 25 \cdot 8 \mathrm{mM}\right.$ $\mathrm{K}^{+}, 199 \cdot 5 \pm 24 \cdot 1 \% ; P<0 \cdot 01$ vs $5.8 \mathrm{mM} \mathrm{K}^{+}, 100$ $\pm 19.9 \%)$, SPP1 $\left(10.8 \mathrm{mM} \mathrm{K}^{+}, 105 \cdot 2 \pm 6 \cdot 0 \%, P=\mathrm{NS}\right.$; $25.8 \mathrm{mM} \mathrm{K}^{+}, 145.6 \pm 16.4 \% ; P<0.05$ vs $5.8 \mathrm{mM} \mathrm{K}^{+}$, $100 \pm 4 \cdot 8 \%)$, MAGI1 $\left(10 \cdot 8 \mathrm{mM} \mathrm{K}^{+}, 180 \cdot 6 \pm 18 \cdot 6 \%\right.$, $P<0.001 ; 25.8 \mathrm{mM} \mathrm{K}^{+}, 315 \cdot 6 \pm 39.7 \% ; P<0 \cdot 001$ vs $\left.5.8 \mathrm{mM} \mathrm{K}{ }^{+}, 100 \pm 3.4 \%\right)$, HMOX2 $\left(10.8 \mathrm{mM} \mathrm{K}{ }^{+}\right.$, $105 \cdot 1 \pm 11 \cdot 1 \%, P=\mathrm{NS} ; 25 \cdot 8 \mathrm{mM} \mathrm{K}{ }^{+}, 143 \cdot 6 \pm 15 \cdot 7 \%$; $P<0.05$ vs $5.8 \mathrm{mM} \mathrm{K}^{+}, 100 \pm 4.3 \%$ ), and $R N F 144 B$ $\left(10.8 \mathrm{mM} \mathrm{K}^{+}, 123.0 \pm 24.9 \%, P=\mathrm{NS} ; 25.8 \mathrm{mM} \mathrm{K}^{+}\right.$, $191 \cdot 0 \pm 23.8 \% ; P<0.05$ vs $\left.5.8 \mathrm{mM} \mathrm{K}^{+}, 100 \pm 19 \cdot 6 \%\right)$ followed potassium-induced upregulation (Fig. 4E).

\section{Analysis of expression levels of candidate genes in aldosterone-producing adenomas}

To further explore the potential relevance of potassium-dependent gene regulation for autonomous aldosterone production causing primary hyperaldosteronism, we analyzed samples of human aldosteroneproducing adenomas for alterations in the expression levels of the previously identified genes in comparison to normal adrenal tissues. While for MTUS1 expression, a significantly lower expression was detectable in aldosterone-producing adenomas in comparison to normal adrenal tissues $(54 \cdot 7 \pm 7 \cdot 1$ vs $100 \pm 17 \cdot 4 \%$; $P=0 \cdot 01$ ), for other genes from set A such as SMOC1, GPR48, TCF4, SOS1, and WWOX, no significant differences between the two groups were evident (Fig. 5A). More significant alterations in gene expression were detectable for genes from set B with NKTR $(202 \cdot 1 \pm 12 \cdot 2$ vs $100 \pm 26 \cdot 2 \% ; P<0 \cdot 05)$, 
A 21971 genes
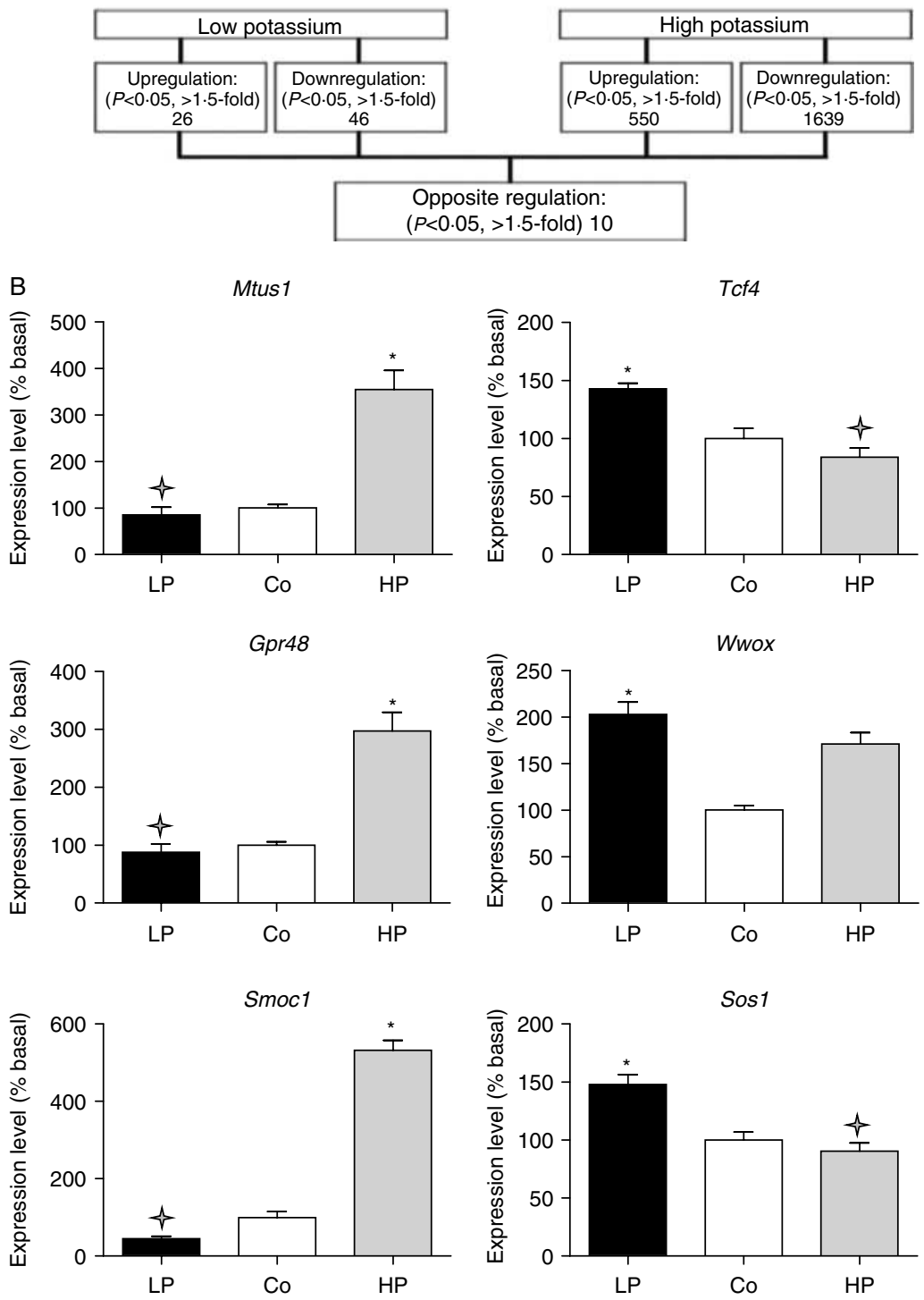

Figure 2 (A) Schematic overview of genes identified by microarray analysis to be significantly regulated in adrenal glands from mice upon long-term low (LP) and high potassium (HP) supplementation in comparison to control animals (Co). (B) Real-time PCR analyses displaying expression levels of selected candidate genes (Mtus1, Tcf4, Gpr48, Wwox, Smoc1, and Sos1) from the same experiment. Asterisks denote significant differences in comparison to untreated controls. Grey stars denote significant differences between the low potassium and the high potassium groups.

LPHN3 $(720 \cdot 6 \pm 75 \cdot 0$ vs $100 \pm 17 \cdot 4 \% ; P=0 \cdot 0002)$, MAGI1 $(267 \cdot 1 \pm 38.3$ vs $100 \pm 23.5 \% ; P<0 \cdot 01)$, and $R N F 144 B(241 \cdot 7 \pm 45 \cdot 1$ vs $100 \pm 20 \cdot 6 \% ; P<0 \cdot 05)$ being significantly upregulated, while SPP1 $(24 \cdot 4 \pm 11 \cdot 7$ vs $100 \pm 26 \cdot 2 \% ; P=0 \cdot 01$ ) being lower expressed in Conn's adenomas in comparison to normal adrenal glands (Fig. 5B).

\section{Discussion}

Although potassium is a well-known secretagogue for aldosterone secretion from the zona glomerulosa, molecular changes in the adrenal gland that are induced by potassium supplementation in vivo have not been defined in detail. As a screening approach, 
A
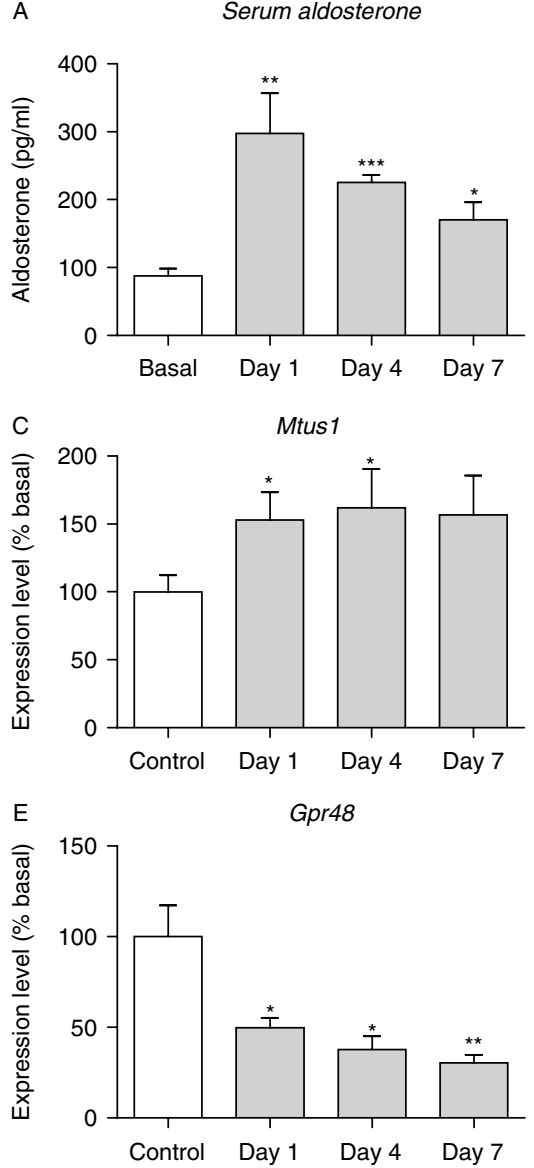

G

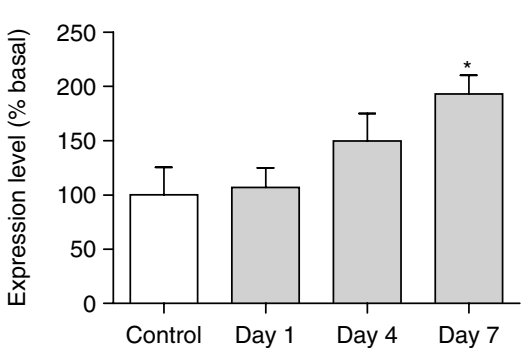

B Cyp11b2
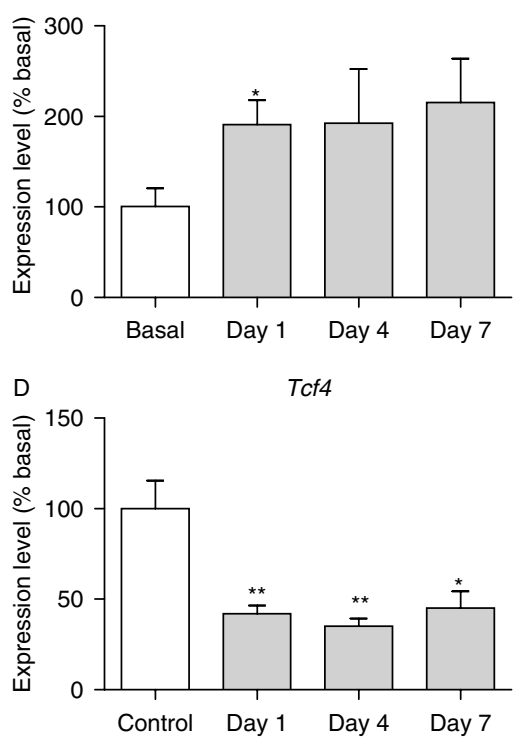

$\mathrm{F}$

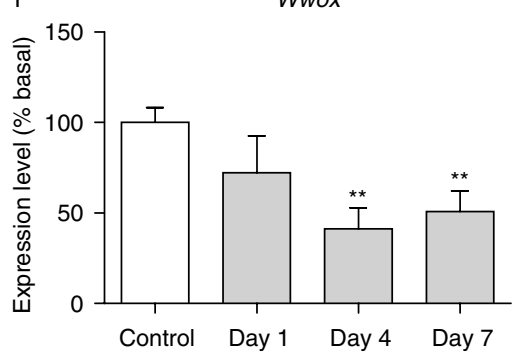

$\mathrm{H}$

Sos1

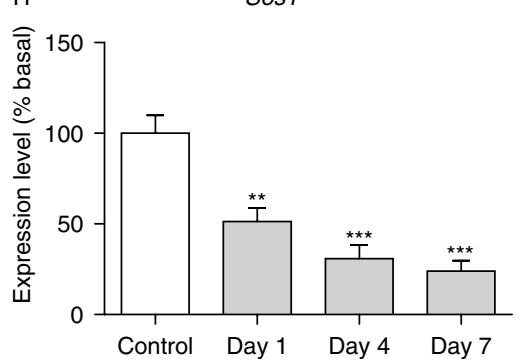

Figure 3 Serum aldosterone levels $(A)$ and adrenal aldosterone synthase expression (B) in wild-type mice after 1,4 , and 7 days of potassium stimulation. (C-H) Effects of short-term potassium stimulation on expression levels of Mtus1 (C), Tcf4 (D), Gpr48 (E), Wwox $(\mathrm{F})$, Smoc1 $(\mathrm{G})$, and Sos1 $(\mathrm{H})$ in murine adrenal glands. Asterisks denote significant differences in comparison to baseline controls.

we applied an experimental paradigm of HP and LP intake in mice that was maintained over 4 weeks and identified genes that displayed opposite changes in expression levels in the LP and HP groups as compared to a Co group of animals.

Diet-induced changes in serum potassium are difficult to induce in the context of normal kidney function. In fact, we were not able to demonstrate significant changes in serum potassium levels between the experimental groups, which are most likely due to compensatory mechanisms including those affecting the renin-angiotensin-aldosterone system. However, as we clearly demonstrate that adrenal expression levels of Cyp11b2 and aldosterone levels in animals can be induced by means of HP intake in a highly significant manner, the applied experimental setting with potassium supplementation was able to provoke expected endocrine changes. Interestingly, only slight 

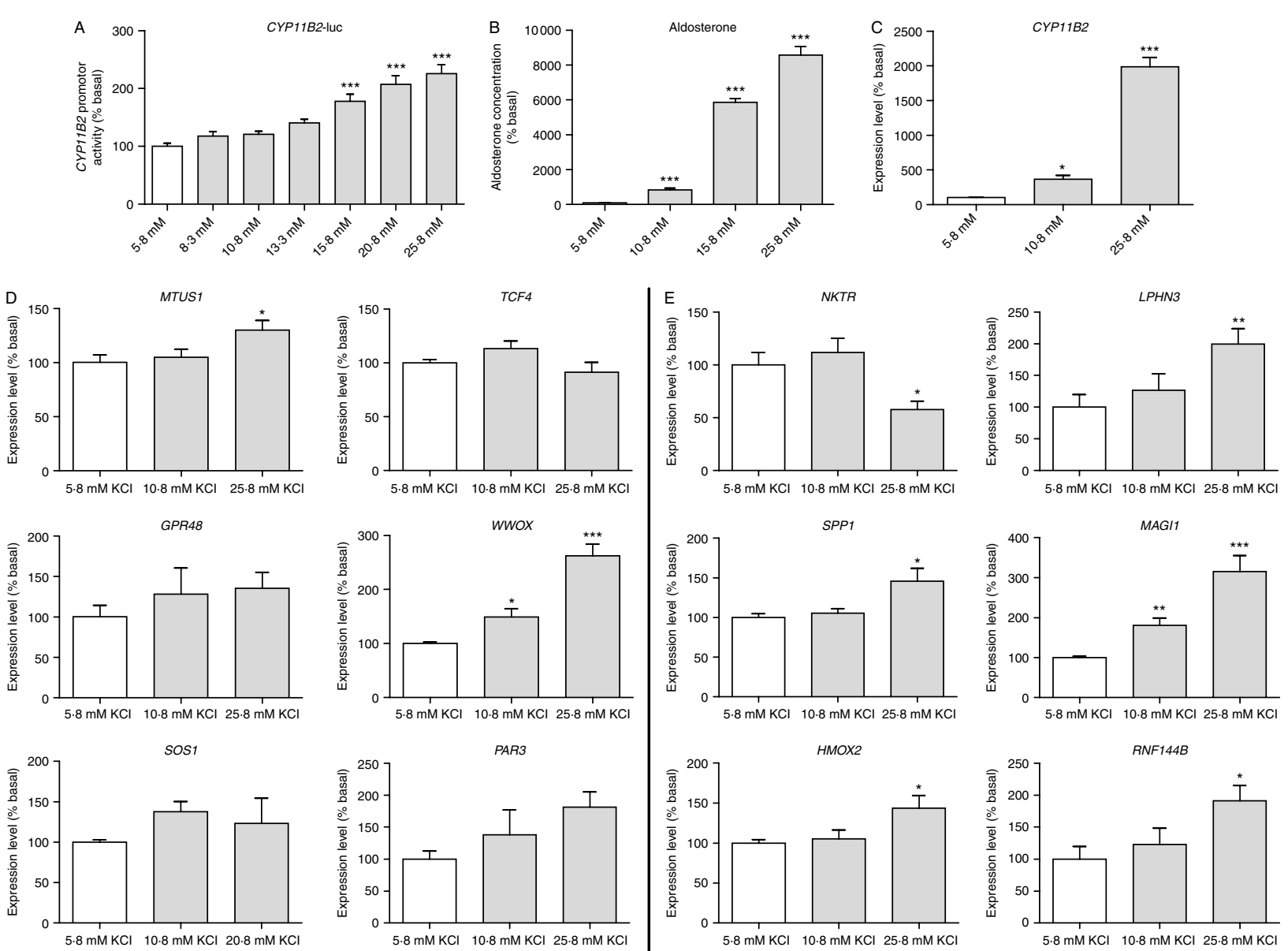

Figure 4 Potassium-dependent increase in CYP11B2 promoter activity (A), secretion of aldosterone (B), and endogenous CYP11B2 expression $(C)$ in $\mathrm{NCl}$ h295R. Effect of potassium stimulation on expression levels of genes from set $A(D)$ and from set $B(E)$ in $N C l$ h295R. Cells were treated with medium supplemented with $5 \mathrm{mM}$ (final concentration $10.8 \mathrm{mM}$ ) or $20 \mathrm{mM}$ (final concentration $25.8 \mathrm{mM}$ ) $\mathrm{KCl}$ for $48 \mathrm{~h}$. Asterisks denote significant upregulation compared with untreated controls $(5 \cdot 8 \mathrm{mM} \mathrm{KCl})$.

enlargement of zona glomerulosa thickness was observable with a concomitant more than tenfold increase in Cyp11b2 expression levels. Thus, in this experimental setting, transcriptional regulation or changes in mRNA stability seem to play a more important role in comparison to morphological changes such as zonation.

Following the chronic potassium stimulation, a set of genes (referred to as set A) including Mtus1, Gpr48, and Smoc1 were found to be upregulated in the HP group, while other genes such as Tcf4, Wwox, and Sos 1 expression were elevated in those animals kept on a LP diet. Five out of six investigated genes displayed the same changes during an independent time course experiment with an observation period between 1 and 7 days. In contrast, expression of Gpr48, which was clearly upregulated after 4 weeks of potassium stimulation was decreasing in a time-dependent fashion within the first week of potassium supplementation. Gpr48, a G-protein-coupled receptor, which is currently classified as an orphan receptor, has been implicated in playing a role in tumor cell invasiveness and metastasis (Gao et al. 2006) and bone remodeling (Luo et al. 2009) among others. Owing to its functional interdependency with cyclin-dependent kinase inhibitor p27 ${ }^{\text {Kipl } 1}$ (Gao et al. 2006), we can only speculate that the observed bimodal regulatory pattern of Gpr 48 could be involved in the regulation of potassium-induced cell cycle control, which differs between the earlier and later observation time points. Furthermore, as animals of different age, gender, and genetic background had been used for the long-term experiments versus shortterm experiments, we cannot exclude the possibility that these factors might have affected $G p r 48$ expression levels. Conversely, the overall similarity of expression patterns despite the differences in the experimental outline provides indirect evidence for a functional relevance of these candidate genes.

Similar to Gpr48, the majority of genes identified by this screening approach have not been described in the 

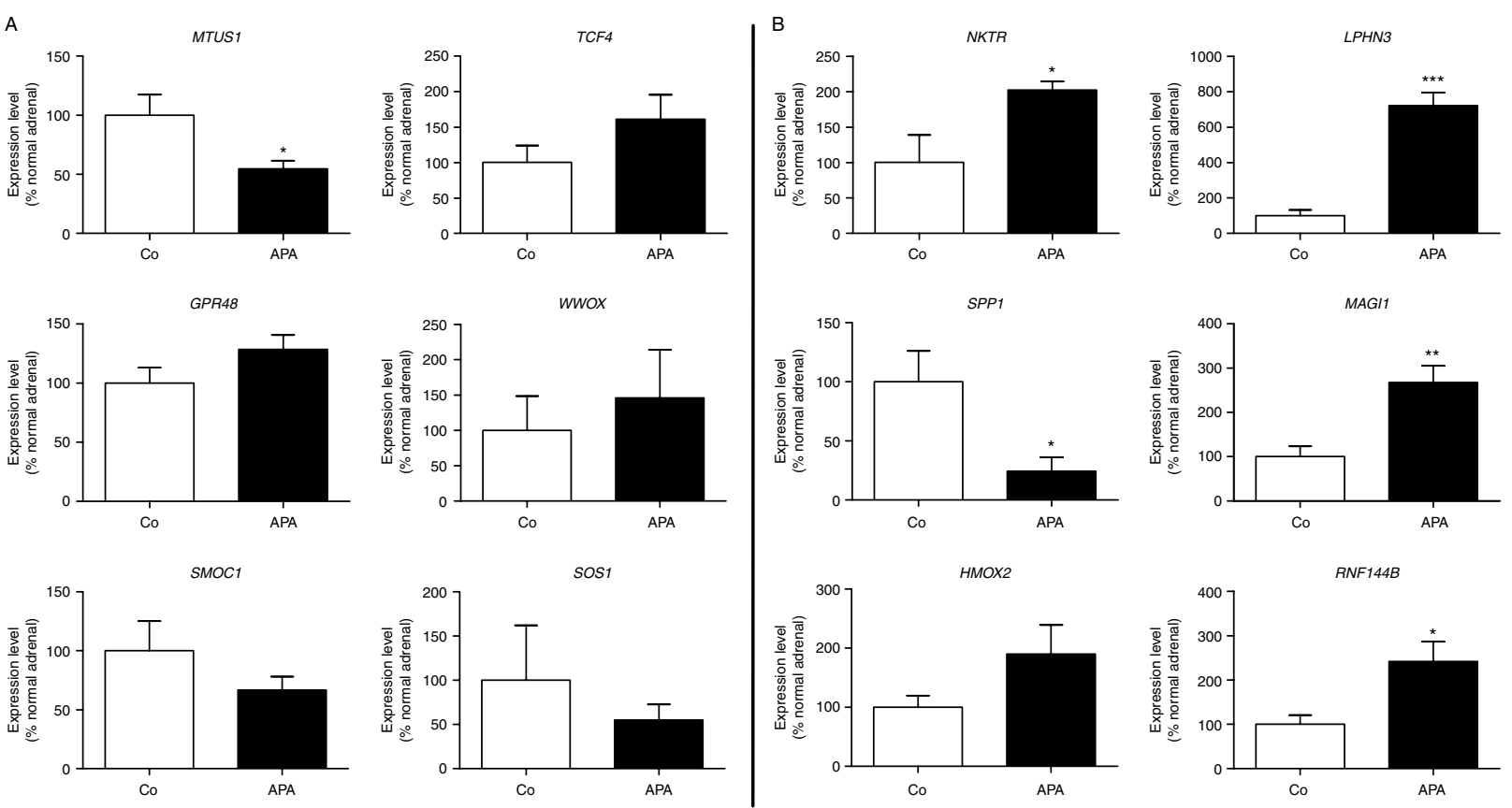

Figure 5 Expression levels of genes from set $A(A)$ and from set $B(B)$ in aldosterone-producing adenomas (APA) in comparison to normal adrenal glands $(\mathrm{Co})$. Asterisks denote significant differences between the two groups.

context of adrenal physiology or aldosterone autonomy (Bassett et al. 2005, Lenzini et al. 2007). In contrast, WWOX, which has been identified as a tumor suppressor gene in a variety of human malignancies (Aqeilan \& Croce 2007), has also been shown to be required for steroidogenesis (Aqeilan et al. 2009). Although the endocrine phenotype in Wwox knockout animals was mainly related to the ovaries and testes, gonadal genes also required for adrenal steroidogenesis such as Cyp11a1 were described to be downregulated in the context of Wwox deficiency. Thus, although it remains to be shown, it is tempting to speculate that WWOX might play a role also in the regulation of potassium-induced aldosterone secretion.

Independent of its assumed function, the observed changes in expression levels in vivo could be interpreted as a direct potassium-induced effect on the adrenal gland or as an indirect effect mediated by other factors, which itself had been modulated by potassium supplementation. In an attempt to differentiate between these two possibilities, we proceeded with in vitro experiments by treating NCI h295R cells with different potassium concentrations. Following these experimental conditions, both an increase in aldosterone release and promoter activation of CYP11B2 were readily detectable in potassium-treated cells. Similarly, the majority of genes identified in the HP group (set B) displayed a potassium-dependent upregulation in NCI h295R cells. In contrast, with exception of MTUS, the expression levels of the predefined genes from set A did not change or - as for WWOX - did display even opposite changes to those observed in vivo. Thus, it is possible that potassium-induced modulation of regulatory networks such as the renin-angiotensin-aldosterone system or the hypothalamus-pituitary-adrenal axis could overcome direct potassium-induced effects on the adrenocortical cell.

However, other potential explanations could also account for the observed discrepancies: although an in vitro approach has the advantage of well-characterized experimental conditions, artifacts induced by the absence of zonal integrity and paracrine networks that also could modulate transcriptional regulation in the glomerulosa cell have to be taken into account. Furthermore, it is possible that species-dependent differences between rodents and humans could apply for potassium-dependent regulation of steroidogenesis. Finally, disruption of regulatory pathways in a tumor cell line might have affected the resulting expression levels that differ from those observed in a normal adrenocortical cell. In fact, genes required for normal aldosterone regulation could provide good candidates for genes that are involved in dysregulation of aldosterone production in primary aldosteronism. Indeed, recent examples from knockout mouse models have highlighted this concept. Specifically, deletion of potassium channels that are required for sensing potassium concentration by the glomerulosa cell such as the large-conductance, voltage- and $\mathrm{Ca}^{2+}$-activated $\mathrm{K}^{+}$(BK) channel (Sausbier et al. 2005) or members of 
the 2P domain family potassium channels TASK1 (Davies et al. 2008, Heitzmann et al. 2008) have been demonstrated to result in a phenotype resembling many aspects of primary aldosteronism.

To collect further indirect evidence for a potential role of the defined candidate genes for dysregulation of aldosterone production in primary aldosteronism, we compared expression levels in aldosteroneproducing adenomas with normal adrenal glands. Autonomous aldosterone secretion in Conn's adenomas is accompanied by low renin levels and (a tendency to) hypokalemia. Thus, expression analysis of the pre-defined candidate genes could provide indirect evidence whether regulation of the gene in a potassium-dependent manner is still intact (downregulated) or possibly part of the autonomous dysregulation (upregulated). Our expression analyses demonstrated a significant downregulation for MTUS1 gene expression in aldosterone-producing adenomas in comparison to normal adrenal tissues, while the remaining genes did not differ significantly between the two groups.

As Mtus1 expression was consistently upregulated in a potassium-dependent manner in vivo and in vitro, we would assume that the observed downregulation in Conn's adenomas should be interpreted as the consequence of lower potassium levels in these patients. Furthermore, the lack of clear-cut changes of the remaining candidate genes from set A makes transcriptional dysregulation as the cause of autonomous aldosterone secretion unlikely. Of those genes with significant differences in expression in Conn's adenomas from set $\mathrm{B}, L P H N 3$ has been described also to be more abundantly expressed in fetal than in adult adrenal glands (Xing et al. 2009). Notably, another of the candidate genes from set B, SPP1, has very recently been identified in meta-analysis of genome-wide gene expression analysis as one of 36 genes for which the expression differed between the pre-hypertensive phase and established hypertension (Marques et al. 2010). As SPP1 coding for secreted phosphoprotein 1 was decreased during the development of hypertension and also lower expressed in Conn's adenomas, these data provide indirect arguments for a potential functional relevance of SPP1 in the pathophysiology of hypertension.

However, a number of limitations have to be taken into account for the interpretation of our findings: first, species differences (mouse versus human) in the regulation of aldosterone secretion could apply. Secondly, an in vitro system is unlikely to reflect all aspects present in an organ and whole organism respectively. Finally, given the fact that aldosterone-producing adenomas might have a phenotype that resembles that of a glomerulosa cell, comparison of expression levels of a Conn's adenoma with whole adrenal glands could overestimate expression of a given gene.

In summary, we have identified a number of genes regulated in vivo in a potassium-dependent manner. Robust differences in expression levels within a specific experimental setting could be observed. However, discrepancies between different in vivo and in vitro paradigms highlight the complexity of potassiumdependent gene regulation that is likely to be modulated within a cellular and endocrine network. Although experimental conditions have to be taken into account for the proper interpretation of these results, the defined candidate genes can serve as the starting point for further functional studies.

\section{Declaration of interest}

The authors declare that there is no conflict of interest that could be perceived as prejudicing the impartiality of the research reported.

\section{Funding}

This study was supported by grants from the Landesstiftung Baden-Württemberg (P-LS-ASN/5) and a grant from the Deutsche Forschungsgemeinschaft (BE2177/8-1) to FB.

\section{Acknowledgements}

The authors thank Lilia Spady and Inga Johnsen for excellent technical assistance and to Dr Martin Bidlingmaier for help with the hormone measurements. The authors are further indebted to Dr Ceslo Gomez-Sanchez (University of Mississippi, Jackson, MS) for providing us with a CYP11B2-promoter construct. This work is part of the doctoral thesis of A D and S S.

\section{References}

Akizuki O, Inayoshi A, Kitayama T, Yao K, Shirakura S, Sasaki K, Kusaka H \& Matsubara M 2008 Blockade of T-type voltagedependent $\mathrm{Ca}^{2+}$ channels by benidipine, a dihydropyridine calcium channel blocker, inhibits aldosterone production in human adrenocortical cell line NCI-H295R. European Journal of Pharmacology 584 424-434. (doi:10.1016/j.ejphar.2008.02.001)

Aqeilan RI \& Croce CM 2007 WWOX in biological control and tumorigenesis. Journal of Cellular Physiology 212 307-310. (doi:10. 1002/jcp.21099)

Aqeilan RI, Hagan JP, de Bruin A, Rawahneh M, Salah Z, Gaudio E, Siddiqui H, Volinia S, Alder H, Lian JB et al. 2009 Targeted ablation of the WW domain-containing oxidoreductase tumor suppressor leads to impaired steroidogenesis. Endocrinology 150 1530-1535. (doi:10.1210/en.2008-1087)

Bassett MH, Suzuki T, Sasano H, White PC \& Rainey WE 2004 $a$ The orphan nuclear receptors NURR1 and NGFIB regulate adrenal aldosterone production. Molecular Endocrinology 18 279-290. (doi:10.1210/me.2003-0005)

Bassett MH, White PC \& Rainey WE $2004 b$ The regulation of aldosterone synthase expression. Molecular and Cellular Endocrinology 217 67-74. (doi:10.1016/j.mce.2003.10.011)

Bassett MH, Mayhew B, Rehman K, White PC, Mantero F, Arnaldi G, Stewart PM, Bujalska I \& Rainey WE 2005 Expression profiles for 
steroidogenic enzymes in adrenocortical disease. Journal of Clinical Endocrinology and Metabolism 90 5446-5455. (doi:10.1210/ jc.2005-0836)

Benjamini Y \& Hochberg Y 1995 Controlling the false discovery rate: a practical and powerful approach to multiple testing. Journal of the Royal Statistical Society. Series B $\mathbf{5 7} 289$.

Betz MJ, Shapiro I, Fassnacht M, Hahner S, Reincke M \& Beuschlein F 2005 Peroxisome proliferator-activated receptor-gamma agonists suppress adrenocortical tumor cell proliferation and induce differentiation. Journal of Clinical Endocrinology and Metabolism 90 3886-3896. (doi:10.1210/jc.2004-1267)

Boldrick JC, Alizadeh AA, Diehn M, Dudoit S, Liu CL, Belcher CE, Botstein D, Staudt LM, Brown PO \& Relman DA 2002 Stereotyped and specific gene expression programs in human innate immune responses to bacteria. PNAS 99 972-977. (doi:10.1073/pnas. 231625398)

Boyd JE \& Mulrow PJ 1972 Further studies of the influence of potassium upon aldosterone production in the rat. Endocrinology 90 299-301. (doi:10.1210/endo-90-1-299)

Boyd JE, Palmore WP \& Mulrow PJ 1971 Role of potassium in the control of aldosterone secretion in the rat. Endocrinology $\mathbf{8 8}$ 556-565. (doi:10.1210/endo-88-3-556)

Brazma A, Hingamp P, Quackenbush J, Sherlock G, Spellman P, Stoeckert C, Aach J, Ansorge W, Ball CA, Causton HC et al. 2001 Minimum information about a microarray experiment (MIAME)toward standards for microarray data. Nature Genetics 29 365-371. (doi:10.1038/ng1201-365)

Cherradi N, Brandenburger Y \& Capponi AM 1998 Mitochondrial regulation of mineralocorticoid biosynthesis by calcium and the StAR protein. European Journal of Endocrinology 139 249-256. (doi:10.1530/eje.0.1390249)

Christenson LK \& Strauss JF III 2001 Steroidogenic acute regulatory protein: an update on its regulation and mechanism of action. Archives of Medical Research 32 576-586. (doi:10.1016/S01884409(01)00338-1)

Clyne CD, Zhang Y, Slutsker L, Mathis JM, White PC \& Rainey WE 1997 Angiotensin II and potassium regulate human CYP11B2 transcription through common cis-elements. Molecular Endocrinology 11 638-649. (doi:10.1210/me.11.5.638)

Condon JC, Pezzi V, Drummond BM, Yin S \& Rainey WE 2002 Calmodulin-dependent kinase I regulates adrenal cell expression of aldosterone synthase. Endocrinology 143 3651-3657. (doi:10.1210/ en.2001-211359)

Curnow KM, Tusie-Luna MT, Pascoe L, Natarajan R, Gu JL, Nadler JL \& White PC 1991 The product of the CYP11B2 gene is required for aldosterone biosynthesis in the human adrenal cortex. Molecular Endocrinology 5 1513-1522. (doi:10.1210/mend-5-10-1513)

Davies LA, Hu C, Guagliardo NA, Sen N, Chen X, Talley EM, Carey RM, Bayliss DA \& Barrett PQ 2008 TASK channel deletion in mice causes primary hyperaldosteronism. PNAS 105 2203-2208. (doi:10.1073/ pnas.0712000105)

Denner K, Rainey WE, Pezzi V, Bird IM, Bernhardt R \& Mathis JM 1996 Differential regulation of 11 beta-hydroxylase and aldosterone synthase in human adrenocortical H295R cells. Molecular and Cellular Endocrinology 121 87-91. (doi:10.1016/0303-7207(96)03853-1)

Dudoit S, Young YH \& Speed T 2002 Statistical methods for identifying differentially expressed genes in replicated cDNA microarray experiments. Statistica Sinica 12111.

Eisen MB \& Brown PO 1999 DNA arrays for analysis of gene expression. Methods in Enzymology 303 179-205.

Fallo F, Veglio F, Bertello C, Sonino N, Della Mea P, Ermani M, Rabbia F, Federspil G \& Mulatero P 2006 Prevalence and characteristics of the metabolic syndrome in primary aldosteronism. Journal of Clinical Endocrinology and Metabolism 91 454-459. (doi:10.1210/jc.2005-1733)

Gao Y, Kitagawa K, Hiramatsu Y, Kikuchi H, Isobe T, Shimada M, Uchida C, Hattori T, Oda T, Nakayama K et al. 2006 Up-regulation of
GPR48 induced by down-regulation of p27Kip1 enhances carcinoma cell invasiveness and metastasis. Cancer Research 66 11623-11631. (doi:10.1158/0008-5472.CAN-06-2629)

Heitzmann D, Derand R, Jungbauer S, Bandulik S, Sterner C, Schweda F, El Wakil A, Lalli E, Guy N, Mengual R et al. 2008 Invalidation of TASK1 potassium channels disrupts adrenal gland zonation and mineralocorticoid homeostasis. EMBO Journal 27 179-187. (doi:10.1038/sj.emboj.7601934)

Kaufman L \& Rousseeuw P 1990. Finding Groups in Data: an Introduction to Cluster Analysis. New York: John Wiley.

Lenzini L, Seccia TM, Aldighieri E, Belloni AS, Bernante P, Giuliani L, Nussdorfer GG, Pessina AC \& Rossi GP 2007 Heterogeneity of aldosterone-producing adenomas revealed by a whole transcriptome analysis. Hypertension 50 1106-1113. (doi:10.1161/HYPERTENSIONAHA.107.100438)

Lin D, Sugawara T, Strauss JF III, Clark BJ, Stocco DM, Saenger P, Rogol A \& Miller WL 1995 Role of steroidogenic acute regulatory protein in adrenal and gonadal steroidogenesis. Science $\mathbf{2 6 7}$ 1828-1831. (doi:10.1126/science.7892608)

Lotshaw DP 2001 Role of membrane depolarization and T-type $\mathrm{Ca}^{2+}$ channels in angiotensin II and $\mathrm{K}^{+}$stimulated aldosterone secretion. Molecular and Cellular Endocrinology 175 157-171. (doi:10.1016/S0303-7207(01)00384-7)

Luo J, Zhou W, Zhou X, Li D, Weng J, Yi Z, Cho SG, Li C, Yi T, Wu X et al. 2009 Regulation of bone formation and remodeling by G-protein-coupled receptor 48. Development 136 2747-2756. (doi:10.1242/dev.033571)

Manolopoulou J, Bielohuby M, Caton SJ, Gomez-Sanchez CE, RennerMueller I, Wolf E, Lichtenauer UD, Beuschlein F, Hoeflich A \& Bidlingmaier M 2008 A highly sensitive immunofluorometric assay for the measurement of aldosterone in small sample volumes: validation in mouse serum. Journal of Endocrinology 196 215-224. (doi:10.1677/JOE-07-0134)

Marques FZ, Campain AE, Yang YH \& Morris BJ 2010 Meta-analysis of genome-wide gene expression differences in onset and maintenance phases of genetic hypertension. Hypertension 56 319-324. (doi:10.1161/HYPERTENSIONAHA.110.155366)

Milliez P, Girerd X, Plouin PF, Blacher J, Safar ME \& Mourad JJ 2005 Evidence for an increased rate of cardiovascular events in patients with primary aldosteronism. Journal of the American College of Cardiology 45 1243-1248. (doi:10.1016/j.jacc.2005.01.015)

Mulatero P, Stowasser M, Loh KC, Fardella CE, Gordon RD, Mosso L, Gomez-Sanchez CE, Veglio F \& Young WF Jr 2004 Increased diagnosis of primary aldosteronism, including surgically correctable forms, in centers from five continents. Journal of Clinical Endocrinology and Metabolism 89 1045-1050. (doi:10.1210/jc.2003-031337)

Pezzi V, Clyne CD, Ando S, Mathis JM \& Rainey WE 1997 Ca(2+)regulated expression of aldosterone synthase is mediated by calmodulin and calmodulin-dependent protein kinases. Endocrinology 138 835-838. (doi:10.1210/en.138.2.835)

Rossi GP, Bernini G, Desideri G, Fabris B, Ferri C, Giacchetti G, Letizia C, Maccario M, Mannelli M, Matterello MJ et al. 2006 Renal damage in primary aldosteronism: results of the PAPY study. Hypertension 48 232-238. (doi:10.1161/01.HYP.0000230444.01215.6a)

Saeger W, Fassnacht M, Chita R, Prager G, Nies C, Lorenz K, Barlehner E, Simon D, Niederle B, Beuschlein F et al. 2003 High diagnostic accuracy of adrenal core biopsy: results of the German and Austrian adrenal network multicenter trial in 220 consecutive patients. Human Pathology 34 180-186. (doi:10.1053/hupa.2003.24)

Sausbier M, Arntz C, Bucurenciu I, Zhao H, Zhou XB, Sausbier U, Feil S, Kamm S, Essin K, Sailer CA et al. 2005 Elevated blood pressure linked to primary hyperaldosteronism and impaired vasodilation in BK channel-deficient mice. Circulation 112 60-68. (doi:10.1161/01.CIR.0000156448.74296.FE)

Sindelka G, Widimsky J, Haas T, Prazny M, Hilgertova J \& Skrha J 2000 Insulin action in primary hyperaldosteronism before and after surgical or pharmacological treatment. Experimental and Clinical Endocrinology and Diabetes 108 21-25. 
Spyroglou A, Manolopoulou J, Wagner S, Bidlingmaier M, Reincke M \& Beuschlein F 2009 Short term regulation of aldosterone secretion after stimulation and suppression experiments in mice. Journal of Molecular Endocrinology 42 407-413. (doi:10.1677/JME-08-0167)

Stowasser M, Sharman J, Leano R, Gordon RD, Ward G, Cowley D \& Marwick TH 2005 Evidence for abnormal left ventricular structure and function in normotensive individuals with familial hyperaldosteronism type I. Journal of Clinical Endocrinology and Metabolism 90 5070-5076. (doi:10.1210/jc.2005-0681)

Tanaka TS, Jaradat SA, Lim MK, Kargul GJ, Wang X, Grahovac MJ, Pantano S, Sano Y, Piao Y, Nagaraja R et al. 2000 Genome-wide expression profiling of mid-gestation placenta and embryo using a 15,000 mouse developmental cDNA microarray. PNAS 97 9127-9132. (doi:10.1073/pnas.97.16.9127)

VanBuren V, Piao Y, Dudekula DB, Qian Y, Carter MG, Martin PR, Stagg CA, Bassey UC, Aiba K, Hamatani T et al. 2002 Assembly, verification, and initial annotation of the NIA mouse 7.4K cDNA clone set. Genome Research 12 1999-2003. (doi:10.1101/gr.633802)

Varnai P, Petheo GL, Makara JK \& Spat A 1998 Electrophysiological study on the high $\mathrm{K}^{+}$sensitivity of rat glomerulosa cells. Pflügers Archiv 435 429-431. (doi:10.1007/s004240050534)

Vasan RS, Evans JC, Benjamin EJ, Levy D, Larson MG, Sundstrom J, Murabito JM, Sam F, Colucci WS \& Wilson PW 2004 Relations of serum aldosterone to cardiac structure: gender-related differences in the Framingham Heart Study. Hypertension 43 957-962. (doi:10. 1161/01.HYP.0000124251.06056.8e)

Widimsky J Jr, Sindelka G, Haas T, Prazny M, Hilgertova J \& Skrha J 2000 Impaired insulin action in primary hyperaldosteronism. Physiological Research 49 241-244.

Williams JS \& Williams GH 2003 50th Anniversary of aldosterone. Journal of Clinical Endocrinology and Metabolism 88 2364-2372. (doi:10.1210/jc.2003-030490)

Xing Y, Nakamura Y \& Rainey WE 2009 G protein-coupled receptor expression in the adult and fetal adrenal glands. Molecular and Cellular Endocrinology 300 43-50. (doi:10.1016/j.mce. 2008.10.036)

Yagci A \& Muller J 1996 Induction of steroidogenic enzymes by potassium in cultured rat zona glomerulosa cells depends on calcium influx and intact protein synthesis. Endocrinology 137 4331-4338. (doi:10.1210/en.137.10.4331)

Received in final form 10 July 2010

Accepted 20 July 2010

Made available online as an Accepted Preprint 20 July 2010 